\title{
Public forest policy development in New Brunswick, Canada: multiple streams approach, advocacy coalition framework, and the role of science
}

\author{
William F. A. Anderson ${ }^{1}$ and David A. MacLean ${ }^{1}$
}

\begin{abstract}
In a 15-year case study, we used the multiple streams approach (MSA) and the advocacy coalition framework (ACF) to examine a controversial industry-led proposal for increased harvest of Crown forests in New Brunswick, Canada, in an adversarial policy subsystem. Study participants were queried on their perceptions of policy problems and reasons for community attention, the relationship between science and policy, and whether policy decisions were consistent with scientific understanding. Thematic analysis was used to examine interview data for evidence of Kingdon's MSA and Sabatier's ACF. During public hearings of a Legislative Select Committee on Wood Supply, two competing policy alternatives emerged. The first, put forward by the forest industry coalition, advocated an intensive forest management approach in support of a competitive industry. The second, supported by the conservation coalition, largely made up of scientists and environmental groups, focused on adaptive management, an ecosystem approach, and greater public input. This counterproposal forestalled the industry from placing its proposal on the government 2005 decision agenda. However, in 2014, the government unexpectedly adopted essentially the same industry proposal. Although the MSA provided a better explanation of the factors critical to the 2014 policy change, i.e., a declining provincial economy and a change of key government personnel, the ACF offered a nuanced perspective on the need for a professional forum to facilitate policy-oriented learning across competing coalitions. In 2014, the lack of such a forum and a closed process limited policy alternatives considered by elected officials. Results also emphasize the importance of how legislators choose to interact with experts and scientists, particularly within an adversarial subsystem, especially when a powerful coalition develops ways to limit the access to decision makers by competing coalitions.
\end{abstract}

Key Words: Crown forests; forest management; forest policy; government agenda; Jaakko Pöyry report; policy; policy-oriented learning; policy windows

\section{INTRODUCTION}

Resource policy controversies often result from changes in societal concerns and values that governments have initially failed to notice or address (Clark et al. 1998, Mills and Clark 2001). Despite efforts to understand how science influences policy (Jasanoff 1990, Lee 1993, Macleod et al. 2008), successful bridges between science and resource policies have proved difficult (Kimmins et al. 2005, Sutherland et al. 2012). The challenge facing scientists and policy makers has been to synthesize existing scientific knowledge and integrate it into a knowledge base that supports policy development (Klenk and Hickey 2011, Nursey-Bray et al. 2014).

Science-based information may be used for different purposes, i.e., learning, instrumental, or political, depending on the level of competition within a policy subsystem (Weible 2008, Weible and Sabatier 2009, Weible et al. 2010). Policy subsystems (Jenkins-Smith et al. 2014) have been characterized as follows: (1) unitary, i.e., dominated by a single coalition with opposition being unorganized and poorly resourced; (2) collaborative, i.e., cooperative coalitions that disagree but find ways to negotiate and work together; or (3) adversarial, i.e., containing rival coalitions, each with incompatible beliefs. Adversarial coalitions are usually anchored by government agencies or a powerful interest group (Weible 2008), and policies are designed with clear winners and losers and little compromise (Weible and Sabatier 2009). Policy processes have been described in terms of the multiple streams approach (MSA) of Kingdon (2003) and the advocacy coalition framework (ACF) of Sabatier (1988).
The MSA (Kingdon 2003, Zahariadis 2014) specifies that the likelihood of a policy proposal, including those that are science based, being adopted by government is the result of the interaction of five structural elements: (1) problems, brought to the attention of government through socioeconomic indicators, by focusing events such as crises and disasters, or through evaluation of government programs; (2) policies, i.e., experts propose solutions that are technically feasible, compatible with decision-maker values, reasonable in cost, and appealing to the public; (3) politics, i.e., political factors, such as changes in government, changes in political mood, political ideology, and the opinions of advocacy or opposition groups, influence agendas; (4) policy windows, i.e., transitory periods of time, when the separate streams of problems, policies, and politics coincide; and (5) policy entrepreneurs, i.e., individuals capable of investing significant time and resources to promote preferred proposals or problems encourage decision makers to pay attention by joining problems and solutions to politics. The MSA permits examination of the actions and motivations of visible, i.e., predominately elected officials, and hidden policy actors, i.e., academics, bureaucrats, and interest groups (Kingdon 2003). Under the MSA, policy actors use science to identify problems and evaluate potential solutions, the effect of science-based information is contingent on the presence of a policy entrepreneur, and policy entrepreneurs use science-based information to shape agendas and policies for political gain (Weible 2008). Science information can be used to maintain the status quo by reinforcing the legitimacy of current processes or to challenge existing processes and expose negative aspects of a policy.

${ }^{1}$ University of New Brunswick, Faculty of Forestry and Environmental Management 
Under the ACF, actors with similar beliefs merge into advocacy coalitions within which they attempt to affect public policy (Sabatier 1988). The ACF assumes that governmental programs are translations of policy-oriented beliefs and because policy core beliefs are rigidly held, major policy change is unlikely as long as the advocacy coalition that instituted the program remains in power (Jenkins-Smith et al. 2014). ACF membership is relatively stable over time (Weible et al. 2009), and actors seeking to influence policy making need to develop an understanding of the details and scale of problems, the causes, and the impacts of proposals. Information is regarded as an important resource, and to understand policy processes, one needs to understand how scientific and technical explanations are used in political debates (Jenkins-Smith et al. 2014). Under the ACF, policy-oriented learning across belief systems is most likely when a forum exists that is prestigious enough to force professionals from different coalitions to participate (Jenkins-Smith et al. 2014). Problems involving natural systems are conducive to policy-oriented learning because many of the critical variables (participants) are not themselves active strategists and because controlled experimentation is more feasible (Weible and Nohrstedt 2012).

We use the MSA and ACF policy frameworks to examine a case study of a long-running, adversarial attempt to influence public forest policy in New Brunswick, Canada (Erdle and MacLean 2005). An industry-led initiative caused significant public controversy regarding provincial Crown lands and intensive forest management (Ashton and Anderson 2005). This case study is of particular interest because industry maintained that its policy proposal was supported by the best available science, and the policy initiative initially failed, but a decade later, in an unexpected shift, government implemented a strikingly similar industrial proposal. Our objectives were to (1) use in-depth interviews, analysis, and the MSA and ACF frameworks to determine reasons why a forest industry policy initiative initially failed but, nearly a decade later, was implemented; (2) examine how scientists and science-based information influenced the development of New Brunswick public forest policy; and (3) elucidate the factors that contributed to significant policy change.

\section{CASE STUDY DESCRIPTION}

New Brunswick is the most forested province in Canada, with $85 \%$ of its 7.3 million ha wooded (Canadian Forest Service 2005). Just over half of this area is publicly owned, i.e., Crown, forests. The New Brunswick Department of Natural Resources (NBDNR) has the mandate to manage these forests in the longterm interests of the public (NBDNR 2006). Howlett and Rayner (1995) characterized the New Brunswick forest policy subsystem as being "captured," in which NBDNR could be characterized as advancing the interests of the forest products industry ahead of its mandate of sustainable management. As such, for more than 2 decades, policy debates over Crown forest management in New Brunswick have been characterized as contested, adversarial, and in a state of gridlock (e.g., Baskerville 1988, Parenteau 2013). The main conflict between the 2 dominant coalitions of forest industry versus forest conservation has been how Crown forests are assigned to meet competing timber production and conservation objectives (Floyd et al. 2012).

By the mid-1970s, it was apparent that the wood-processing capacity of industry exceeded the sustainable wood supply
(Baskerville 1982). The wood-supply problem was mainly the result of forest age structure and major expansion of the forest products industry (Baskerville 1982). The province responded with the implementation of the Crown Lands and Forests Act in 1982 (Baskerville 1995), under which the sustainable harvest level is set as the nondeclining volume of wood that can be harvested for at least 80 years into the future (Select Committee on Wood Supply [SCWS] 2004). Under the act, the minister of natural resources is uniquely responsible for the development, utilization, protection, and integrated management of Crown lands and, with the approval of the lieutenant governor in council, may enter into agreements with persons or organizations for any purpose related to the Crown Lands and Forests Act. This permits parceling of Crown forests into timber licenses, using a legal contract with the forest product companies that operate processing facilities in the province. A 5-year, "evergreen" planning cycle enables Crown forest management to respond to changes in social values, economic situations, resource information, and scientific knowledge about forest dynamics. For each 5-year cycle, forest management goals and objectives are detailed 2 years in advance, in a document commonly known as the "Vision document" (e.g., NBDNR 1999). Under the act, there is no requirement for public input or legislative oversight of changes to policy or agreements entered into by the minister.

During the 1980s and 1990s, there was growing concern among scientific and conservation communities that the diversity of native species and ecological processes were inadequately protected under the New Brunswick forest management system (LaPierre 1997). In 2000, in response to these concerns and pledges under the 1992 National Forest Strategy and the Canadian Biodiversity Strategy, the government proposed to set aside 10 large, ecologically significant areas, totaling 150,000 ha, and applied a harvest moratorium removing the proposed protected areas from active forest management (Ashton et al. 2007). Industry predicted that adverse economic impacts and job losses would result if the Protected Areas Strategy was adopted (Ashton and Anderson 2005). In September 2001, in a letter to the minister of natural resources, the New Brunswick Forest Products Association demanded that government adopt a 6-point action plan that included the following: doubling the future harvest of Crown forests; holding government and licensees financially accountable for achieving forest management objectives; implementing an intensive silviculture program to achieve the wood-supply objectives; applying third-party performance audits; requiring environmental certification of all Crown land; and streamlining management procedures (Ashton and Anderson 2005).

In response to these demands, NBDNR and industry jointly commissioned Jaakko Pöyry Consulting, an international consulting firm, to examine the stewardship of Crown lands (Jaakko Pöyry Consulting 2002). The report New Brunswick Crown Forests: Assessment of Stewardship and Management, commonly known as the Jaakko Pöyry report (JPR), included a scenario that projected doubling the future Crown forest harvest and recommendations to improve public participation, forest management, biodiversity, and research on Crown forests. Doubling future harvests was projected to be possible through intensive and extensive use of forest plantations, precommercial thinning, and an increase in the government silviculture budget 
from Can $\$ 23$ million to Can\$34 million per year (Jaakko Pöyry Consulting 2002).

Significant concerns were raised by academia, environmental nongovernmental organizations (ENGOs), and the public over the widespread use of forest plantations, potential negative effects on biodiversity and wildlife habitat, and suggested changes to Crown forest governance (Erdle and MacLean 2005). These concerns led to the formation of an all-party Legislative SCWS charged with "conducting public consultation into the subject of wood supply in the province and to respond specifically to recommendations" in the JPR (SCWS 2004:i). In September 2004, following 13 public hearings with more than 200 speakers, 121 written submissions, and numerous technical presentations from experts, the SCWS tabled its final report containing 25 recommendations covering 4 broad policy areas: governance and accountability, forest management objectives, allocation of resources and distribution of benefits, and provincial wood supply (SCWS 2004). In brief, the SCWS rejected the JPR scenario of doubling Crown harvest and recommended that the province should maintain the diversity of the Acadian forest, as well as provide greater opportunities for public participation in the setting of forest management objectives (SCWS 2004).

For the decade following the SCWS, successive governments sponsored numerous expert task forces, panels, and reports. Notable among these were Management Alternatives for New Brunswick's Public Forest: Report of the New Brunswick Task Force on Forest Diversity and Wood Supply (Erdle 2008), commonly known as the Erdle report, and Future Opportunities for the Forest Products Industry in New Brunswick: Report of the Task Force on Investment Opportunities in the New Brunswick Forest Sector, often referred to as the Roberts report (Roberts and Woodbridge 2008). The Erdle report provided a range of alternative scenarios and projected outcomes for the future management of Crown forests, whereas the Roberts report described the long-term economic and export opportunities for the provincial forest sector. The intent of government was to juxtapose the ecological possibilities and constraints of Crown forests contained in the Erdle report with the economic feasibility of the Roberts report (Beckley 2014). Nonetheless, for all intents and purposes, there was no major change to forest policy or the Crown forest management. Moreover, governments generally adopted a closed, less consultative approach to forest policy development (Beckley 2014).

On 12 March 2014, the New Brunswick government unexpectedly released a new forestry strategy, A Strategy for Crown Lands Forest Management: Putting our Resources to Work (NBDNR 2014), just 2 years after the launch of a 10-year plan. Through an aggressive harvest strategy that reduced harvest restrictions in designated conservation areas, the new strategy increased the annual allowable harvest of spruce (Picea) and balsam fir (Abies balsamea) by an estimated $20 \%$. The new policy represented a significant departure from the long-held policy of conservation values being addressed prior to setting industrial timber allocations. Furthermore, according to government officials, the new plan would "encourage investment, maintain thousands of jobs, create hundreds of new jobs and manage Crown forests in a sustainable way" (New Brunswick government press release, 12 March 2014). Officials also emphasized that the approach could save taxpayers several millions of dollars annually.
Following nearly a decade and a half of intense lobbying, industry finally gained a guaranteed timber objective. Under terms contained in memoranda of agreement, the increased timber supply for industry was guaranteed for 25 years. Legal experts suggested that options of future governments to modify or cancel the agreements were particularly limited ("J.D. Irving forestry deal 'already done,' expert says" 2014). The contracts stipulated that industry was required to invest in mills, but only if market conditions were favorable. In contrast, the agreements placed detailed obligations on government to provide an increased industrial wood supply.

Reaction to this policy shift was contentious, with industry predictably endorsing the approach, whereas other stakeholder groups raised concerns about the absence of transparency and public consultation and that a number of SCWS recommendations were ignored. In an open letter to the minister of natural resources, 184 university professors and other academics criticized the new policy and noted that the strategy was formulated behind closed doors and "has serious conservation shortcomings, has questionable socio-economic benefits for the public, limits the government's ability to shape future forest policy, and potentially compromises government's management oversight of the public forest" ("184 professors demand halt to Crown forest policy" 2014). The signatories also called on government to "immediately halt its current course of action, assemble the collective wisdom that has been accumulated over the past number of years through reports/studies and academic research, and revisit the strategy" ("184 professors demand halt to Crown forest policy” 2014).

During the September 2014 provincial election campaign, Premier Alward promoted his Conservative Party platform on an aggressive natural resource development strategy. The government had already finalized the forestry contracts just days before the election writ was issued ("Crown forestry deal will be finalized within days, Alward says" 2014). Brian Gallant's Liberal Party criticized the plan before the election and during the campaign committed to reviewing the forestry agreements if it came to power. However, just 6 months into its 4-year mandate, the Gallant government announced that it would respect contracts signed with forestry companies, including the guaranteed increases for Crown wood allocations (The Canadian Press 2015).

\section{METHODS}

Our analysis focuses on the New Brunswick forest policy case study events between March 2000 and March 2015, including the commissioning and release of the JPR, release of the SCWS final report, the ensuing government response to the SCWS report, and events surrounding the adoption of the 2014 forest strategy. We evaluate the actions and motivations of elected officials, bureaucrats, industry executives, representatives of ENGOs, and scientists and academics involved in events surrounding the New Brunswick forest policy subsystem. Using a modified snowball technique (Weible et al. 2010), we identified organizations and individuals involved in forest management issues in New Brunswick, using background material from the Internet, government reports, press releases, and media articles (Birkland 2004, Michaels et al. 2006). Potential study participants from government, industry, and ENGOs active in the events surrounding the JPR were verbally briefed as to our objectives and methods and were then invited to be interviewed. 
Table 1. Summary of case study participants and their respective roles.

\begin{tabular}{|c|c|c|c|c|c|c|c|}
\hline & $\begin{array}{c}\text { Senior Government } \\
\text { Bureaucrat }\end{array}$ & $\begin{array}{l}\text { Industry } \\
\text { Executive }\end{array}$ & $\begin{array}{l}\text { Elected } \\
\text { Official }\end{array}$ & $\begin{array}{c}\text { Environmental } \\
\text { Nongovernmental } \\
\text { Organization }\end{array}$ & $\begin{array}{l}\text { Adviser or } \\
\text { Expert }\end{array}$ & Media Official & Total \\
\hline $\begin{array}{l}\text { Number of } \\
\text { participants }\end{array}$ & 3 & 4 & 2 & 2 & 2 & 1 & 14 \\
\hline Participant code & $\begin{array}{l}\text { BUR-01 } \\
\text { BUR-02 } \\
\text { BUR-03 }\end{array}$ & $\begin{array}{l}\text { IND-01 } \\
\text { IND-02 } \\
\text { IND-03 } \\
\text { IND-04 }\end{array}$ & $\begin{array}{l}\text { EO-01 } \\
\text { EO-03 }\end{array}$ & $\begin{array}{l}\text { ENGO-01 } \\
\text { ENGO-02 }\end{array}$ & $\begin{array}{l}\text { ADV-01 } \\
\text { ADV-02 }\end{array}$ & MED-01 & \\
\hline
\end{tabular}

Data were collected from 14 volunteer participants during inperson or telephone interviews in 2009. Participants included senior bureaucrats, forest-industry executives, advisers/experts, members of ENGOs, elected officials, and 1 media representative. Table 1 provides a summary of the participants and their respective roles. On average, interviews were 1.5 hours in duration. Interview recordings were transcribed, and copies provided to the respective participants to ensure accuracy of transcription (Fontana and Frey 2000, Yin 2003). Each participant was assigned a code (Table 1) to enable traceability of quotes while ensuring anonymity. An interview guide (Kingdon 2003) was used during the interviews to probe interviewee perceptions of major policy problems and reasons for community attention (Table 2). Participants were also questioned regarding their observations concerning the relationship between science and policy, also known as policy proximity (Jung 1999), and whether policy decisions were consistent with current scientific understanding, commonly known as a science consistency check (Everest et al. 1997).

Thematic analysis, a method for identifying, analyzing, and reporting repeated patterns, i.e., themes, within qualitative data (Boyatzis 1998, Braun and Clarke 2006), was used to examine interview transcript data for evidence of the MSA (Kingdon 2003), problems, policies, and politics, as well as indications of whether scientific information was used during the agenda setting process. NVivo was used to assist in the categorization, sorting, and reorganizing of meaningful segments of text related to our objectives. Additional data, consisting of copies of presentations made during public hearings, were obtained from the SCWS secretariat. Particular care was given to acquire documents from individuals who self-identified as scientists, and thematic analysis was used to capture comments about consequences of implementing the JPR scenario of doubling the Crown harvest. Identified themes were collated and sorted by frequency of occurrence using NVivo coding queries (Bazeley and Jackson 2013).

Supplemental telephone interviews were also conducted between January and March of 2015 to determine the factors and individuals involved with the decisions surrounding the closed 2014 policy process. In total, six interviews were conducted with data being collected from individuals from academic, bureaucratic, advisory, political, conservation, and woodlot organizations.
Table 2. Summary of interview questions.

\begin{tabular}{l}
\hline Topic Questions \\
\hline
\end{tabular}

Personal and contextual

Could you briefly describe your background?

Education? Work experience?

What was your role in the Jaakko Pöyry case?

Multiple streams approach (Kingdon 2003)

What major issues were you and others in the forest sector most occupied with those days?

Why do you think these particular issues were the ones that received attention; how did they come to be the hot issues? What were the drivers?

What were you and other people in the forest sector working on at that time, in the way of new approaches or new programs; what was on the front burner?

Why do you think these particular proposals were being seriously considered? How did they come to be the hot proposals?

Is there anything else that you think I might be interested in?

Policy proximity (Jung 1999)

What was the scope of the science advisory process?

Was the process limited to biophysical science, or did it consider socioeconomic science as well?

Did the process evaluate or formulate policy options to address the policy issue?

What was the strength of the institutional linkages to the decision-making process?

Was there commitment by policy makers to base future decisions only on the advisory process outcomes, or was it one of many sources of information?

Were there provisions to solicit advice on a regular basis or only on an ad hoc basis?

Science consistency check (Everest et al. 1997)

In your opinion, was all relevant scientific information made available to managers/decision makers considered in the decision?

Was scientific information understood and correctly interpreted?

Were resource risks associated with decisions acknowledged and documented? 


\section{RESULTS}

We use the MSA and ACF to examine events and actions of policy actors within this case study.

\section{The problem}

The 2001 New Brunswick Forest Products Association letter to government identified a wood-supply problem and suggested the association's preferred solution of intensifying forest management on Crown forests. Industry feedback to government was clear: for industry to remain competitive, more wood was needed. For a number of years, forest industry had repeatedly advanced an intensified forest management approach through bilateral negotiations with the NBDNR (Ashton and Anderson 2005). Interviewee IND-02 summed up these efforts by stating: "That was a culmination really, that letter, of many discussions between the industry and the government for years really, at least 3 or 4 years prior to that, where the industry was asking for action and with $[\mathrm{sic}]$ no avail." From the perspective of industry, a stable or increasing wood supply was unquestionably linked to industrial competitiveness. The forest products industry argued that the softwood harvest, also known as the annual allowable cut, had decreased from the previous decade. Indeed, the annual softwood harvest level in New Brunswick was 3.8 million $\mathrm{m}^{3}$ from 1982 to 1986, increased to 4.2 million $\mathrm{m}^{3}$ from 1987 to 1991 , but then declined to 3.3-3.5 million $\mathrm{m}^{3}$ from 1992 to 2007 (NBDNR 2004).

A leaked copy of the 2001 industry letter was obtained by the Conservation Council of New Brunswick, an ENGO, which subsequently publicized its concerns over implications of the industry policy proposal. During a press conference, the Conservation Council offered a different problem definition emphasizing the need to maintain healthy ecosystems, conserve wildlife habitat, and create a democratic process to examine future access, tenure, and management of Crown forests. From the previous material and additional related quotes from study participants (Table 3), it is evident that there were repeated attempts to deal with the perceived problem of industrial wood supply, consistent with Kingdon's MSA problem stream.

\section{Policy}

Kingdon's MSA policy stream centers on proponents' proposed solutions to problems (Kingdon 2003). Within the policy stream, bureaucrats, researchers, and interest groups evaluate and debate alternatives, thereby narrowing the range of choices for decision makers. "Surviving" proposals emerge and constitute a short list to which decision makers give serious consideration.

Policy entrepreneurs typically "soften up" the policy community and the public to overcome inertia and gain the approval of elected officials (Kingdon 2003). Undeniably, industry policy entrepreneurs attempted to influence elected officials before, during, and after release of the JPR. In September 2003, industry representatives met with members of the New Brunswick Cabinet to discuss an implementation plan for major elements of the JPR, two months before the start of SCWS public hearings. When the Conservation Council of New Brunswick learned of this bilateral policy process through right-to-information legislation, it went to the media. An industry spokesperson approached by the media confirmed that they had submitted a plan to the province, stating that the document "only outlines what the industry would like to see happen if the province accepts the Jaakko Pöyry report's recommendations" (Folkins 2003).
In addition to making repeated efforts to influence elected officials and bureaucrats, industry also promoted its proposal to the general public. In a newspaper article, the president of the Forest Products Association stated: "I expect we will double our production of lumber over the next 50 years" (McKillop 2002). These comments actually came 7 months before release of the JPR.

The JPR also gained the attention of NBDNR bureaucrats not normally involved in Crown timber allocation negotiations. In April 2003, an internal NBDNR committee was charged with reviewing the report, developing response options, and providing ministerial recommendations. By creating an intradepartmental consultation process, experts within NBDNR provided wideranging advice to senior departmental managers. Prior to establishment of the NBDNR committee, professionals had been essentially excluded from past department-industry wood-supply discussions. As stated by interviewee BUR-02: "I didn't want brown envelopes floating around [leaking documents to the media] or people spouting off because there was no other avenue for them to let me and the Department know how they felt about the [JPR] recommendations." In its final report, the NBDNR review committee noted that resource management required balancing economic, ecological, and social factors, as well as meaningful public consultation to determine what kind of forest and industry the people of New Brunswick wanted (NBDNR 2004). With respect to implementing the JPR scenario of doubling Crown harvest, staff concluded that additional analysis was warranted (NBDNR 2004). Not only was the NBDNR review report intended to inform senior departmental managers, but it was also used during briefings held in camera for SCWS elected officials: "They had the report given to them ..., and we brought some of our people in to answer questions too that were more specific and scientifically based" (interviewee BUR-03). From the previous discussion and additional quotes from study participants (Table 3), it is apparent that the industry-preferred solution to the wood-supply problem was receiving considerable attention within the policy stream.

\section{Politics}

The likelihood that a policy proposal achieves government agenda status depends on (1) whether it is consistent with the prevailing public mood, (2) whether it fits within the orientation of the current administration, and (3) the degree of support or opposition from interest groups (Kingdon 2003). Public opinion can affect policy outcomes by enabling participants to place issues on the government agenda or by restraining them from doing so (Kingdon 2003). Bureaucrat BUR-02 offered considerable insight into the industry expectations and the intensifying public mood opposed to doubling the harvest of Crown forests: "Stakeholders already felt the forest industry was the big bully and that it always got what it wanted ... Certainly the forest industry totally underestimated their reaction was going to get [sic]. They thought they could do the study, it would be their license to go ahead."

Elected official EO-O3 also noted that the industry proposal was at odds with public sentiment, pointing to the public backlash during the SCWS hearings: "They [industry] were not expecting that new step [public hearings], and they were not expecting that reaction and the outrage from the public." Elected official EO-01 also suggested that the public hearings helped gauge public mood 
Table 3. Study participant responses, Kingdon (2003) multiple streams approach.

\begin{tabular}{lcc}
\hline \hline & & Kingdon Multiple Streams Approach \\
\cline { 2 - 3 } Study Participant Role & Problem Stream $^{\dagger}$ & Policy Stream $^{\ddagger}$ \\
\hline Adviser & A1 & B \\
Bureaucrat & B1, B2 & B \\
Elected official & & B4 \\
$\begin{array}{l}\text { Environmental nongovernmental } \\
\text { organization }\end{array}$ & & EO3 \\
$\begin{array}{l}\text { Industry } \\
\text { Media }\end{array}$ & I1 EO2 & ENG1 \\
\hline
\end{tabular}

'Problem stream:

A1. "Every 5 years there was always a set of guidelines ... there was usually specific objectives for wildlife ... for other things, but not necessarily for wood. And that was always, that always was struck in their [industry] craw."

B1. "When they [industry] signed on to the Crown Lands and Forest Act in 1982 and the understanding was is they're going to have lots of wood supply ... that wasn't happening, so they basically drafted that letter to try to encourage or pressure government."

B2. "They felt it was time that they had to speak up, and get their message heard, that if New Brunswick wanted a forest industry going forward and they wanted the industry to invest; that government basically had to have some wood-supply objectives."

I1. "It [the letter] certainly was instrumental, and that was a culmination really that letter, of many discussions between the industry and the government for years really."

Policy stream:

B3. "I naively thought that, well no, we're hiring this expert consulting firm who's an expert on forestry ... so when this report comes out it will be a good road map, people will basically say ok, they've gone out and got an objective opinion. Of course that's not what happened."

EO1. "So industry was supporting it [JPR] because they believed at that time it was, wow, it will be more volume for us and that's what we need."

EO2. "We had a firm from outside where they've got probably four species left in their country coming in and giving us a report on how we should manage our forest, and the first copy, draft copy says no more hardwood. Eh? ... But the industry was supporting it! That's fine, so I told [name of NBDNR bureaucrat], I said, it will create a shock."

ENG1. "One thing that did resonate with people was this notion that at least from the letter, that licensees [industry] wanted some kinds of, wanted the public in a sense to provide guarantees to them on wood supply."

I2. "The industry was very concerned about the continual degradation of the AAC [annual allowable cut] by different other uses that was [sic] being prescribed either internally or external to the Department of Natural Resources, affecting the net available wood for the industry ... It had been depleting since 1982, and industry wanted to put some more balance in the Act."

M1. "The doubling idea and the plantation idea something that was very clear maybe because it was just so clearly going in a certain direction that it was impossible to ignore."

${ }^{\S}$ Politics stream:

A2. "You don't have public hearings for everybody to stand up and applaud and say things are wonderful ... they have them 'cause people don't like what's happening."

B4. "Within the department is that there were a lot of foresters and forest technicians who thought it [JPR] was terrible ... that licensees [industry] talked a better story than they actually delivered."

EO3. "There'll never be enough wood, because if you produce more wood, they'll [industry] improve their technology and they will process more wood ... they will not create more jobs."

I3. "I think that Jaakko Pöyry particular [sic] when you have so many strong opposition groups to some of the basic elements in there ... you can easily mount an attack against it."

I4. "Premier [Bernard] Lord told us emphatically that we got to build a base of support, and then when you rally the troops around it, I'll come in and I'll put my stamp for approval on it. Which kind of really set us back, 'cause we ended up getting a totally different perspective of why we had done this."

I5. "They [industry] were overzealous in being happy with the study supporting a lot of their findings and their direction ... and didn't consider their ramifications and the communications and how this would play out in the public realm and in the political realm."

M2. "It may have been such an empirically bad idea that the facts spoke for themselves. Doubling of the harvest and more plantations that really it was so dramatic a change in one direction that there wasn't any way to dress it up."

M3. "Somewhere in the process, whether it was a bureaucrat or the scientists or [premier] Lord or someone at some point said, like slow down, this is too much, we are not going to rush into this. And I don't know who, but it seems clear that some, like the image of superman slowing down the runaway train."

M4. "A [sic] industry friendly report supported by, among other, the biggest industrial name in the province, that makes a compelling argument about needing to do this ... is going to be adopted piece meal [sic], that there is somewhere in that debate something happened to try to slow this down, and succeeded in slowing it down."

concerning the industry proposal. With respect to the SCWS report, interviewee EO-01 further added: "There's been no larger, in terms of public participation, consultation on public policy, aside from a general election, in the province's history ... the largest single block of the recommendations deal with different mechanisms for public input, for public review or scrutiny of what is going on Crown land." Just several weeks after SCWS hearings, industry policy entrepreneurs were again pressing for quick 
action. During a major forestry conference, an industry representative stated: "If we cannot go forward [implement the JPR doubling scenario], we run out of wood, our mills cannot expand, we cannot invest more money, jobs are going to go down and we're going to be shutting down mills" (Malo 2004).

In his refinement of the MSA, Zahariadis (1995, 1999, 2003) showed that the politics stream within a Westminster-based political system is dominated by political parties, and congruence of a proposal with party ideology is nearly always needed for its adoption. Interviewee IND-02 clearly felt that the JPR was ultimately used for purposes other than soliciting government action: "The outcome of the public debate [SCWS hearings] became the advice that the government used rather than the recommendations of their consultants [JPR]." Similar views concerning political preferences and public mood influencing the SCWS were also expressed by interviewee BUR-02: "We had people, a lot of people, who were against any more intensive forest management, that we'd gone way too far ... it had a great influence on the Select Committee." Interviewee BUR-01 also noted that many of the commitments contained in the government response to the SCWS (NBDNR 2005) were consistent with the SCWS recommendations: "I think it [government response] was pretty consistent with what the Select Committee was saying." Additional participant quotations included in Table 3 provide further evidence that within the politics stream, elected officials and the public were unreceptive to the industry proposal.

\section{Scientists and science advice in the policy process}

\section{0-2005 Policy process}

Bureaucrat BUR-01 noted that the desire to have forest management based on the best available science raised significant issues over the interpretation of science and how science-based information supported public policy, and that ultimately, conflicting interpretations led to the creation of the SCWS: "Everybody maybe had different points of view on science ... and I think that sort of what led to the Select Committee." The establishment of the SCWS proved to be a critical decision by government officials, and from an ACF perspective, it may be viewed as the creation of a professional forum that was dominated by rules of a legislative committee process and important enough to force professionals from the industry and conservation coalitions to participate. As noted by elected official EO-03, the SCWS was the first time in more than 2 decades that scientists had a formal venue for providing advice to government: "It was probably one of the first chances for the scientists, since the 70's, to have a say or to have some input ... I would say there was a shift doing that debate." In fact, 17 scientists, external to government, participated in the SCWS public proceedings, providing oral and written briefs. Because of space limitations, we have limited discussion to the 5 issues most frequently raised by scientists as identified during thematic analysis of SCWS documents.

Of the 17 scientists, 13 openly questioned the validity of the facts or the analysis contained in the JPR (Fig. 1). Contrary to assertions contained in the JPR that New Brunswick could double its long-term supply of softwood "while meeting all other environmental and social objectives for Crown Land" (Jaakko Pöyry Consulting 2002:6), 12 scientists cautioned SCWS members about the potential loss of biodiversity and the adverse effects of intensive forest management (Fig. 1). Directly refuting the JPR, 1 scientist stated: "If New Brunswick were to strive to double our wood supply, there is no doubt that there would be a very profound negative effect on our province's biodiversity" (SCWS secretariat, personal communication). Surprisingly, 11 of the 17 scientists also offered views on possible economic and social issues should the JPR scenario of doubling Crown harvest be implemented (Fig. 1). As 1 scientist suggested: "More attention needs to be paid to the value and quality of forest and products produced, instead of just volume" (SCWS secretariat, personal communication). Another openly questioned the wisdom of the JPR recommendation concerning oversight of Crown forests by stating: "It does not seem wise to leave the responsibility of monitoring industry compliance with industry, which has a primary interest in maximizing sustainable harvest" (SCWS secretariat, personal communication). Yet another researcher raised the issue of ignorance concerning the possible ecological effects of the extensive use of plantations: "For many species and ecosystem functions we simply do not know. There has not been enough research done" (SCWS secretariat, personal communication). Another scientist raised the additional challenge of a changing climate, in which: "Large-scale conversion to conifer plantations raises many serious concerns, each one likely to be exacerbated in coming decades by expected climate warming" (SCWS secretariat, personal communication).

Fig. 1. Top five issues raised by scientists during Select Committee on Wood Supply proceedings.

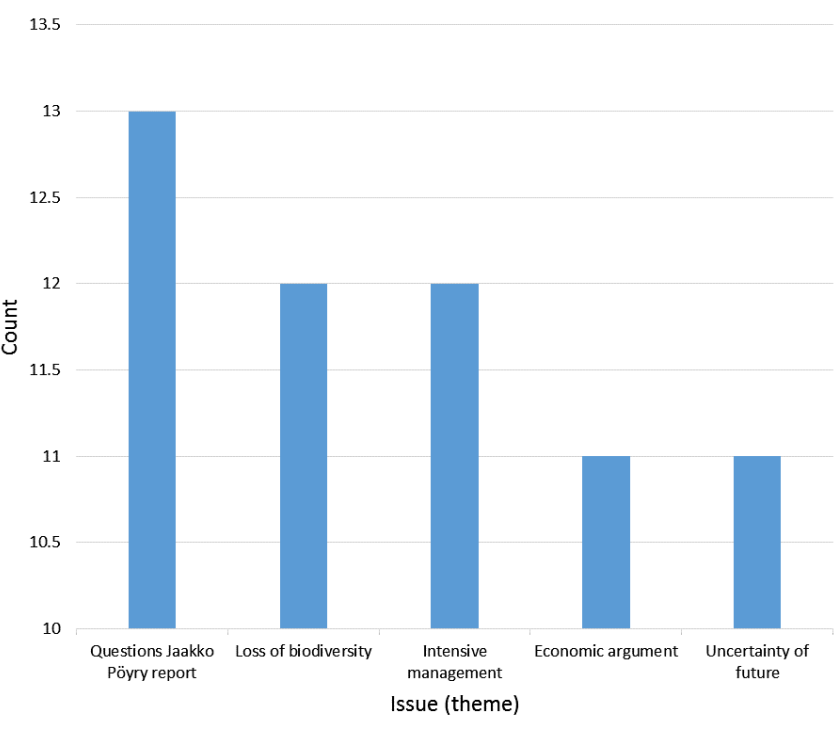

In contrast, a looming industrial crisis featured prominently in the forestry products industry presentations to the SCWS. James Irving Jr., CEO of the largest forest products company in New Brunswick, cautioned SCWS elected officials that there would be dire consequences if government disregarded the industry proposal: "Doubling the manufacturing base is essential to ensuring competitiveness ... A secure wood supply is the banker's first question - new investment is dependent on wood supply ... We need a vision today - and for the future — so that we can avoid the tragic end that shipbuilding has experienced in Canada" 
(SCWS secretariat, personal communication). Industry also was adamant that current forest management practices were science based and that forest productivity could be increased while maintaining biodiversity. As one industry representative put it: "All we can do is rely on the best science available. This is what we do in forestry anyway, as a matter of course. With a commitment to science-based continuous improvement, and the will to make adjustments when necessary, we can take the responsible course that serves all the diverse needs and purposes of a forest, both economic and environmental" (SCWS secretariat, personal communication).

When questioned about the interactions between scientists and elected officials, interviewee BUR-03 stated: "The UNB [University of New Brunswick] paper was one that the Select Committee really hung on to." Elected official EO-01 also furnished additional insight concerning the critical role played by university scientists during the SCWS processes: "The education that they [scientists] provided in terms of a background to making some of the decisions, to making some of the recommendations that the committee actually or eventually did was absolutely vital." Interviewee EO-01 also noted the significant influence of one university professor as adviser to the SCWS: "He was a key part of the whole process ..., he was a teacher, he was a sounding board, he was everything in between and he certainly helped to bring focus to the topics at hand." Indeed, bureaucrat BUR-02 remarked that SCWS elected officials were mindful of the advice given by scientists: "So the Select Committee at least was wise enough to say what you guys [government] need is more science - a lot more science - and you guys need to focus not just on intensive forest management, but management of diversity of the forest long-term." As stated earlier, the Erdle report (Erdle 2008) was one of the major studies directly tied to the government response to the SCWS.

\section{Policy process}

All six supplemental (2015) interviewees stated that the declining state of the provincial economy was the major factor in the government shift in forest policy. Moreover, an unpublished internal NBDNR report identified a significant competitiveness gap facing the forest products sector. To stay competitive, aging mills needed to invest approximately half a billion Canadian dollars to modernize. However, for more than a decade, the forest products industry had insisted that capital investment would only happen with an increased and guaranteed wood supply. As noted by one senior bureaucrat: "There was a greater sense of urgency that if we [government] didn't do something in 2014, it would be even worse down the road, from an economic stand point ... There was a willingness on the part of industry to step up and put some investment in it, to be competitive long-term, and they [elected officials] said OK, we're going to bite the bullet" (supplemental interview, 2015).

Three informants also noted a change in key personnel within NBDNR during a 2013 cabinet shuffle, with the incoming minister and deputy minister being transferred from the provincial economic development portfolio and both having a proindustry attitude. The declining state of the provincial economy and a change in key ministerial personnel were also identified by Beckley (2014) as key factors contributing to the major policy shift.
Following the release of the 2014 forest strategy, the Alward government maintained that there had been sufficient public consultation. The premier claimed that more than a dozen reports had been completed and that it was time for action. Conversely, how government used or considered the reports or past consultations was never clarified (Beckley 2014). Further, two consecutive ministers of natural resources have maintained that the 2014 forest strategy was based on "good science"; however, evidence for this assertion has not been released. In fact, one member of the current provincial legislature claimed that the science supporting the strategy did not exist, and that the harvest of Crown forests was “deemed unsustainable by the Minister's staff, endangering wildlife populations" (Coon 2015). These claims are consistent with a recent performance audit by the provincial auditor general, which observed that economic development was the primary focus of NBDNR and that this would likely impact on the long-term biodiversity of the Crown forest (Auditor General for New Brunswick 2015).

Just days after the release of the new strategy, industry took a different tack, with the head of the largest forest company in the province committing to reverse direction if anyone could produce "good science" that showed that current forest practices were harmful to the environment ("Jim Irving defends New Brunswick forest practices, expanded cut" 2014). Nevertheless, despite assertions by 182 academics and researchers about serious conservation shortcomings and questionable socioeconomic benefits, 2 successive governments and industry have unwaveringly executed the new strategy.

\section{DISCUSSION}

The Kingdon (2003) MSA provides considerable insight concerning the initial inability of industry policy entrepreneurs to link the perceived wood-supply problem and their proposed solution to the government decision agenda. Within the bilateral discussions between NBDNR and industry, there had been little serious vetting of the industry proposal, and there was limited opportunity and time for what Kingdon (2003:116-117) refers to as "natural selection or re-mixing of ideas." Although the Kingdon (2003) selection criteria of technical feasibility was considered, industry entrepreneurs failed to anticipate future constraints such as public acceptability, economic constraints, and receptivity by politicians. Consistent with the findings of Birkland (1997) and McConnell (2010), this failure was subsequently used by members of the conservation coalition, notably scientists and ENGOs, to question the industry proposal and the legitimacy of closed policy processes between government and industry.

During the SCWS process, two competing policy alternatives emerged. The first, proposed by the forest industry coalition, was principally the implementation of the JPR scenario of doubling Crown harvest in support of a competitive forest products sector. The second, advocated by the conservation coalition made up of academics and the ENGO community, focused on an integrated management approach that balanced environmental, social, and economic values while conserving ecological functions of the forest. Scientists also stressed the need to deal with uncertainties surrounding the effects of intensive forest management through supplementary analysis and research. One possible explanation for the inclusion of socioeconomic arguments by the conservation 
coalition is that scientists were attempting to better communicate advice using terms and concepts that would be easily understood by elected officials (Watson 2005, 2012). Another explanation could be that scientists assumed that using economic and social dimensions would reinforce the biophysical or ecological advice offered. These results suggest potential areas for future policy research concerning the motivation of scientists on whether they become involved in policy processes and produce policy-relevant material.

The government response to the SCWS (NBDNR 2005) was consistent with the advice offered by scientists during the SCWS hearings. In fact, government action items included developing strategies for conserving the unique ecological features of the Acadian forest; implementing a forest management strategy that balanced environmental, social, and economic values; developing better public participation and advisory processes; and developing a value-added strategy. Despite the lack of an explicit commitment by elected officials to use science-based information in the development of public forest policy, there can be little doubt that advice from scientists influenced the 2005 approach set out by government.

With respect to the 2014 policy process, success of the 15 -year lobbying effort by industry can largely be explained by a political party adopting an election platform of jobs and economic growth through the development of natural resources to deal with a sagging provincial economy and finding an industry proposal consistent with its theme. As related by a longtime member of the Legislative Assembly, James Irving approached Premier Alward and, in exchange for a guaranteed and increased wood supply, offered a possible solution to the economic crisis facing New Brunswick that would in the process generate needed jobs and economic growth (Kirk MacDonald, 18 September 2014, personal communication).

From an ACF perspective, even though changes to socioeconomic conditions are considered necessary but insufficient conditions for policy change, major policy change would not be predicted because the dominant, i.e., forest industry, coalition was still in power. Furthermore, with respect to policy-oriented learning, as demonstrated by the protracted and continuing policy debate we have discussed throughout, there is little supporting evidence for the hypothesis that problems involving natural systems are more conducive to learning across belief systems than those involving purely social or political systems, i.e., "learning hypothesis 4" (Weible and Nohrstedt 2012). Furthermore, although there is little evidence of between-coalition policy-oriented learning involved in the 2014 policy process, there is substantial evidence of policy-oriented learning within the forest industry coalition. It is apparent that forest industry policy entrepreneurs in New Brunswick learned from their past missteps and successfully linked the perceived wood-supply problem and their preferred solution to the Alward government agenda of creating jobs and encouraging economic growth through natural resource development.

A new strategy employed by policy entrepreneurs within the forest industry coalition was the use of bilateral legal instruments such as memoranda of agreement and modified forest management agreements to enshrine policy in legally binding documents and essentially limit access and recourse of the opposing conservation coalition. Under the terms of these 25-year agreements, mutual consent of both parties is now required for changes to the goals, objectives, evaluation criteria, and management approach of Crown forests. Similar to strategies reported by Meijerink and Huitema (2010) and Huitema and Meijerink (2010), when forest industry policy entrepreneurs gained support of the central decision makers, i.e., the premier, NBDNR minister, and deputy minister, they were effective in achieving policy change by strategically framing a proposal. In addition, they also succeeded through the use of bilateral contractual arrangements that manipulated the composition of the decision-making forum so as to only have forest industry members represented, as well as exclude or bypass other potential adversarial coalitions.

\section{CONCLUSIONS}

Through elite informant interview data and by using complementary frameworks of the MSA and ACF, we have explored a 15-year case study of attempts to alter forest policy in New Brunswick. The MSA was useful in explaining how problems were brought to the attention of legislators, how potential solutions, i.e., proposals, were developed, and how and why individual problems became government priorities. In this case, although industry policy entrepreneurs had considerable political connections, resources, and negotiating skills and were persistent in their efforts to link the perceived problem of reduced Crown forest harvests to their preferred solution of intensive management, they were initially unsuccessful in getting the problem and their solution on the government decision agenda. The industry strategy of appealing to facts in the JPR was unsuccessful because the data and their interpretation were contested by other groups, notably scientists, ENGOs, and bureaucrats.

Initially, scientists and science-based advice influenced the policy debate because of their direct interaction with elected officials through a formal consultation process of the SCWS. From an ACF viewpoint, scientists featured prominently in this adversarial policy subsystem, and the SCWS democratic forum gave them the opportunity to directly inform and advise elected officials. Scientists produced policy-relevant material that identified biophysical and socioeconomic issues and highlighted uncertainties, risks, and costs/benefits associated with the JPR scenario of doubling Crown harvest. Similarly, by creating an internal departmental process, NBDNR experts who has been excluded previously from the timber allocation process, provided advice to the elected officials of the SCWS and senior NBDNR management.

Although the MSA, in our view, provided a better explanation of the factors, i.e., economic and social indicators, and individuals, i.e., entrepreneurs, critical to the 2014 policy change in New Brunswick forest policy, the ACF offered a more nuanced and theory-based perspective concerning the need for a professional forum, i.e., SCWS, to facilitate policy-oriented learning across competing coalitions within an adversarial subsystem. Undeniably, the lack of such a forum in 2014 limited the scope of policy alternatives considered by elected officials in addressing the dire economic conditions of the province. The primary reason for the 2014 policy change was political response, with an upcoming election, to reelection prospects and economic factors.

Finally, our results emphasize the importance of how legislators choose to interact with experts and scientists, particularly within an adversarial subsystem, especially when a powerful coalition 
can, under certain conditions, successfully limit public discourse and input from researchers and scientists. In contrast, transparent processes that actively solicit views of divergent stakeholder groups and experts are more likely to result in policy that is acceptable to the majority of the public.

Responses to this article can be read online at: http://www.ecologyandsociety.org/issues/responses. $\mathrm{php} / 7795$

\section{Acknowledgments:}

We wish to thank the anonymous reviewers whose thoughtful comments on an earlier version of the manuscript led to major improvements. We also thank the anonymous study volunteers for sharing their candid views concerning the events surrounding this critical time in New Brunswick forest policy. Finally, we would like to express our sincere appreciation for the unlimited access to the documents and other material offered by the Secretariat for the Select Committee on Wood Supply, which made this work a reality.

\section{LITERATURE CITED}

Ashton, W., and B. Anderson. 2005. New Brunswick's "Jaakko Pöyry" report: perceptions of senior forestry officials about its influence on forest policy. Forestry Chronicle 81:81-97. http://dx. doi.org/10.5558/tfc81081-1

Ashton, W., T. Needham, and T. Beckley. 2007. How is Crown forest policy developed? Probing New Brunswick's protected areas strategy. Forestry Chronicle 83:689-698. http://dx.doi. org/10.5558/tfc83689-5

Auditor General of New Brunswick. 2015. Report of the Auditor General of New Brunswick. Volume II, infection prevention and control in hospitals, silviculture, private wood supply. Legislative Assembly of New Brunswick, Fredericton, New Brunswick, Canada.

Baskerville, G. L. 1982. The sprucelfir wood supply problem in New Brunswick. Forest Management Branch, Department of Natural Resources, Fredericton, New Brunswick, Canada.

Baskerville, G. L. 1988. Redevelopment of a degrading forest system. Ambio 17:314-322.

Baskerville, G. L. 1995. The forestry problem: adaptive lurches of renewal. Pages 37-102 in L. H. Gunderson, C. S. Holling, and S. S. Light, editors. Barriers and bridges to the renewal of ecosystems and institutions. Columbia University Press, New York, New York, USA.

Bazeley, P., and K. Jackson. 2013. Qualitative data analysis with NVivo. Sage, Thousand Oaks, California, USA.

Beckley, T. 2014. Public engagement, planning, and politics in the forest sector in New Brunswick, 1997-2014. Journal of New Brunswick Studies 5:41-65.

Birkland, T. A. 1997. After disaster: agenda setting, public policy, and focusing events. Georgetown University Press, Washington, D.C., USA.
Birkland, T. A. 2004. Introduction: risk, disaster, and policy in the 21 st century. American Behavioral Scientist 48:275-280. http:// dx.doi.org/10.1177/0002764204268997

Boyatzis, R. 1998. Transforming qualitative information: thematic analysis and code development. Sage, Thousand Oaks, California, USA.

Braun, V., and V. Clarke. 2006. Using thematic analysis in psychology. Qualitative Research in Psychology 3:77-101. http:// dx.doi.org/10.1191/1478088706qp063oa

Canadian Forest Service. 2005. The state of Canada's forests 2004-2005: the boreal forest. Natural Resources Canada, Canadian Forest Service, Ottawa, Ontario, Canada.

The Canadian Press. 2015. N.B. government says it will respect forestry contracts signed by Tories. CTV Atlantic News. 19 March. [online] URL: http://ctv.news/Q2ZqNPT

Clark, R. N., E. E. Meidinger, G. Miller, J. Rayner, M. Layseca, S. Monreal, J. Fernandez, and M. Shannon. 1998. Integrating science and policy in natural resource management. Lessons and opportunities from North America. General Technical Report PNW-GTR-441. Pacific Northwest Research Station, U.S. Forest Service, Portland, Oregon, USA.

Coon, D. 2015. Member's statement - forestry bill 2nd reading, MLA David Coon leader of the Green Party, June 3, 2015. David Coon, MLA, Fredericton South, Fredericton, New Brunswick, Canada. [online] URL: http://davidcoonmla.ca/membersstatement-forestry-bill-2nd-reading-mla-david-coon-leader-of-thegreen-party-june-3-2015/

Crown forestry deal will be finalized within days, Alward says. 2014. CBC News. 12 August;Sect. Canada: New Brunswick. [online] URL: http://www.cbc.ca/1.2734409

Erdle, T. 2008. Management alternatives for New Brunswick's public forest: report of the New Brunswick Task Force on Forest Diversity and Wood Supply. New Brunswick Department of Natural Resources, Fredericton, New Brunswick, Canada.

Erdle, T., and D. A. MacLean. 2005. Forest management in New Brunswick - the Jaakko Pöyry study, the Legislative Select Committee on Wood Supply, and where do we go from here? Forestry Chronicle 81:92-96. http://dx.doi.org/10.5558/tfc81092-1

Everest, F. H., D. N Swanston, C. G. Shaw III, W. P. Smith, K. R. Julin, and S. D. Allen. 1997. Evaluation of the use of scientific information in developing the 1997 forest plan for the Tongass National Forest. General Technical Report PNW-GTR-415. Pacific Northwest Research Station, U.S. Forest Service, Portland, Oregon, USA.

Floyd, D. W., R. Ritchie, and T. Rotherham. 2012. New approaches for private woodlots: reframing the forest policy debate. Private Forest Task Force Report. Province of New Brunswick, Fredericton, New Brunswick, Canada.

Folkins, T. 2003. Group worries province might have less control over forests: document concerns environmental organization. New Brunswick Telegraph-Journal. 4 December;Sect. News.

Fontana, A., and J. H. Frey. 2000. The interview: from structured questions to negotiated text. Pages 645-669 in N. K. Denzin and 
Y. S. Lincoln, editors. Handbook of qualitative research. Second edition. Sage, Thousand Oaks, California, USA.

Howlett, M., and J. Rayner. 1995. Do ideas matter? Policy network configurations and resistance to policy change in the Canadian forest sector. Canadian Public Administration 38:382-410. http://dx.doi.org/10.1111/j.1754-7121.1995.tb01055. $\underline{\mathrm{x}}$

Huitema, D., and S. Meijerink. 2010. Realizing water transitions: the role of policy entrepreneurs in water policy change. Ecology and Society 15(2):26. [online] URL: http://www.ecologyandsociety. org/vol15/iss2/art26/

Jaakko Pöyry Consulting. 2002. New Brunswick Crown forests: assessment of stewardship and management. New Brunswick Department of Natural Resources and the New Brunswick Forest Products Association, Fredericton, New Brunswick, Canada.

Jasanoff, S. 1990. The fifth branch: science advisors as policymakers. Harvard University Press, Cambridge, Massachusetts, USA.

J.D. Irving forestry deal 'already done,' expert says. 2014. $C B C$ News. 30 April;Sect. Canada: New Brunswick. [online] URL: http://www.cbc.ca/1.2627236

Jenkins-Smith, H. C., D. Nohrstedt, C. M. Weible, and P. A. Sabatier. 2014. The advocacy coalition framework: foundations, evolution, and ongoing research. Kindle locations 4008-4884 in P. Sabatier and C. M. Weible, editors. Theories of the policy process. Kindle edition. Third edition. Westview, Boulder, Colorado, USA.

Jim Irving defends New Brunswick forest practices, expanded cut. 2014. CBC News. 17 March;Sect. Canada: New Brunswick. [online] URL: http://www.cbc.ca/1.2575389

Jung, W. 1999. Expert advice in global environmental decision making: how close should science and policy get? Global Environmental Assessment Project, Environmental Natural Resources Program Discussion Paper E-99-14. Belter Center for Science and International Affairs, John F. Kennedy School of Government, Harvard University, Cambridge, Massachusetts, USA.

Kimmins, J. P., C. Welham, B. Seely, M. Meitner, R. Rempel, and T. Sullivan. 2005. Science in forestry: why does it sometimes disappoint or even fail us? Forestry Chronicle 81:723-734. http:// dx.doi.org/10.5558/tfc81723-5

Kingdon, J. 2003. Agendas, alternatives and public policies. Second edition. Longman, New York, New York, USA.

Klenk, N. L., and G. M. Hickey. 2011. Government science in forestry: characteristics and policy utilization. Forest Policy and Economics 13:37-45. http://dx.doi.org/10.1016/j.forpol.2010.08.005

LaPierre, L. 1997. Protected areas strategy for New Brunswick. Éléments: Online Environmental Magazine. [online] URL: http:// www.elements.nb.ca/theme/pa/louis/louis.htm

Lee, K. N. 1993. Compass and gyroscope: integrating science and politics for the environment. Island, Washington, D.C., USA.

Macleod, C. J. A., K. L. Blackstock, and P. M. Haygarth. 2008. Mechanisms to improve integrative research at the science-policy interface for sustainable catchment management. Ecology and Society 13(2):48. [online] URL:http://www.ecologyandsociety. org/vol13/iss $2 / \operatorname{art} 48 /$

Malo, J. 2004. Industry pins hopes on Jaakko Pöyry; politicians need to take wood supply report seriously, says forest products association boss. New Brunswick Telegraph-Journal. 14 February; Sect. Money.

McConnell, A. 2010. Policy success, policy failure and grey areas in-between. Journal of Public Policy 30:345-362. http://dx.doi. org/10.1017/S0143814X10000152

McKillop, D. 2002. Consultant eyeing N.B. woodlands. Daily Gleaner (Fredericton). 6 May;Sect. News.

Meijerink, S., and D. Huitema. 2010. Policy entrepreneurs and change strategies: lessons from sixteen case studies of water transitions around the globe. Ecology and Society 15(2):21. [online] URL: http://www.ecologyandsociety.org/vol15/iss2/ $\underline{\operatorname{art} 21 /}$

Michaels, S., N. P. Goucher, and D. McCarthy. 2006. Policy windows, policy change, and organizational learning: watersheds in the evolution of watershed management. Environmental Management 38:983-992. http://dx.doi.org/10.1007/s00267-005-0269-0

Mills, T. L., and R. N. Clark. 2001. Roles of research scientists in natural resource decision-making. Forest Ecology and Management 153:189-198. http://dx.doi.org/10.1016/S0378-1127 (01)00461-3

New Brunswick Department of Natural Resources and Energy (NBDNR). 1999. A vision for New Brunswick forests: goals and objectives for Crown land management (revised 10 March 2000). NBDNR, Fredericton, New Brunswick, Canada.

New Brunswick Department of Natural Resources (NBDNR). 2004. Staff review of the Jaakko Pöyry report. New Brunswick Crown forests: assessment of stewardship and management. NBDNR, Fredericton, New Brunswick, Canada.

New Brunswick Department of Natural Resources (NBDNR). 2005. Looking to the future: our public forests. Government's response to the Select Committee on Wood Supply. NBDNR, Fredericton, New Brunswick, Canada.

New Brunswick Department of Natural Resources (NBDNR). 2006. The public forest: state of the forest report 2006. NBDNR, Fredericton, New Brunswick, Canada.

New Brunswick Department of Natural Resources (NBDNR). 2014. A strategy for Crown lands forest management: putting our resources to work. NBDNR, Fredericton, New Brunswick, Canada. [online] URL: http://www2.gnb.ca/content/dam/gnb/ Departments/nr-rn/pdf/en/ForestsCrownLands/AStrategyForCrownLandsForestManagement.pdf

Nursey-Bray, M. J., J. Vince, M. Scott, M. Haward, K. O’Toole, T. Smith, N. Harvey, and B. Clarke. 2014. Science into policy? Discourse, coastal management and knowledge. Environmental Science \& Policy 38:107-119. http://dx.doi.org/10.1016/j. envsci.2013.10.010

184 professors demand halt to Crown forest policy. 2014. $C B C$ News. 16 May;Sect. Canada: New Brunswick. [online] URL: http://www.cbc.ca/1.2644958 
Parenteau, W. 2013. Looking backward, looking ahead: history and future of the New Brunswick forest industries. Acadiensis XLII:92-113.

Roberts, D., and P. Woodbridge. 2008. Future opportunities for the forest products industry in New Brunswick: report of the Task Force on Investment Opportunities in the New Brunswick Forest Sector. Department of Natural Resources, Fredericton, New Brunswick, Canada.

Sabatier, P. A. 1988. An advocacy coalition framework of policy change and the role of policy-oriented learning therein. Policy Sciences 21:129-168. http://dx.doi.org/10.1007/BF00136406

Select Committee on Wood Supply (SCWS). 2004. Final report on wood supply in New Brunswick. Legislative Assembly of New Brunswick, Fredericton, New Brunswick, Canada.

Sutherland, W. J., L. Bellingan, J. R. Bellingham, J. J. Blackstock, R. M. Bloomfield, M. Bravo, V. M. Cadman, D. D. Cleevely, A. Clements, A. S. Cohen, D. R. Cope, A. A. Daemmrich, C. Devecchi, L. Diaz Anadon, S. Denegri, R. Doubleday, N. R. Dusic, R. J. Evans, W. Y. Feng, H. C. J. Godfray, P. Harris, S. E. Hartley, A. J. Hester, J. Holmes, A. Hughes, M. Hulme, C. Irwin, R. C. Jennings, G. S. Kass, P. Littlejohns, T. M. Marteau, G. McKee, E. P. Millstone, W. J. Nuttall, S. Owens, M. M. Parker, S. Pearson, J. Petts, R. Ploszek, A. S. Pullin, G. Reid, K. S. Richards, J. G. Robinson, L. Shaxson, L. Sierra, B. G. Smith, D. J. Spiegelhalter, J. Stilgoe, A. Stirling, C. P. Tyler, D. E. Winickoff, and R. L. Zimmern. 2012. A collaboratively-derived sciencepolicy research agenda. PLOS ONE 7(3):e31824. http://dx.doi. org/10.1371/journal.pone.0031824

Watson, R. T. 2005. Turning science into policy: challenges and experiences from the science-policy interface. Philosophical Transactions of the Royal Society B 360:471-477. http://dx.doi. org/10.1098/rstb.2004.1601

Watson, R. T. 2012. The science-policy interface: the role of scientific assessments-UK National Ecosystem Assessment. Proceedings of the Royal Society A 468:3265-3281. http://dx.doi. org/10.1098/rspa.2012.0163

Weible, C. M. 2008. Expert-based information and policy subsystems: a review and synthesis. Policy Studies Journal 36:615-635. http://dx.doi.org/10.1111/j.1541-0072.2008.00287.x

Weible, C. M., and D. Nohrstedt. 2012. The advocacy coalition framework: coalitions, learning and policy change. Kindle Locations 4339-4755 in J. R. A. Eduardo, S. Fritzen, M. Howlett, M. Ramesh, and X. Wu, editors. Routledge handbook of public policy. Kindle edition. Taylor and Francis, New York, New York, USA.

Weible, C. M., A. Pattison, and P. A. Sabatier. 2010. Harnessing expert-based information for learning and the sustainable management of complex socio-ecological systems. Environmental Science \& Policy 13:522-534. http://dx.doi.org/10.1016/j. envsci.2010.05.005

Weible, C. M., and P. A. Sabatier. 2009. Coalitions, science, and belief change: comparing adversarial and collaborative policy subsystems. Policy Studies Journal 37:195-212. http://dx.doi. org/10.1111/j.1541-0072.2009.00310.x
Weible, C. M., P. A. Sabatier, and K. McQueen. 2009. Themes and variations: taking stock of the advocacy coalition framework. Policy Studies Journal 37:121-140. http://dx.doi.org/10.1111/ j.1541-0072.2008.00299.X

Yin, R. K. 2003. Case study research design and methods. Sage, Thousand Oaks, California, USA.

Zahariadis, N. 1995. Markets, states, and public policies: privatization in Britain and France. University of Michigan Press, Ann Arbor, Michigan, USA.

Zahariadis, N. 1999. Ambiguity, time, and multiple streams. Pages 73-93 in $\mathrm{P}$. Sabatier, editor. Theories of the policy process. Westview, Boulder, Colorado, USA.

Zahariadis, N. 2003. Ambiguity and choice in public policy: political decision making in modern democracies. Georgetown University Press, Washington, D.C., USA.

Zahariadis, N. 2014. Ambiguity and multiple streams. Kindle Locations 558-1297 in P. Sabatier and C. M. Weible, editors. Theories of the policy process. Kindle edition. Third edition. Westview, Boulder, Colorado, USA. 